\title{
KAJIAN MODEL ALTMAN Z-SCORE DALAM MENDETEKSI POTENSI KEBANGKRUTAN BANK
}

\author{
Hayanuddin Safri \\ Dosen Tetap Sekolah Tinggi Ilmu Ekonomi (STIE) Labuhan Batu
}

\begin{abstract}
ABSTRAK
Dengan berdasarkan penelitian analisa diskriminan, Altman melakukan penelitian untuk mengembangkan model baru untuk memprediksikan kebangkrutan perusahaan. Model yang dinamakan Z-Score dalam bentuk aslinya adalah model linier dengan rasio keuangan yang diberi bobot untuk memaksimalkan kemampuan model tersebut dalam memprediksi. Model " $Z$ " yaitu nilai yang menunjukkan kondisi perusahaan, apakah dalam keadaan sehat atau tidak dan menunjukkan kinerja perusahaan yang sekaligus merefleksikan prospek perusahaan dimasa mendatang. Dalam menyusun model, Z-Altman mengambil sampel 33 perusahaan manufaktur yang bangkrut pada periode 1960 sampai 1965 dan 33 perusahaan yang tidak bangkrut dengan lini industry dan ukuran yang sama. Dengan menggunakan data laporan keuangan dari 1 sampai 5 tahun sebelum kebangkrutan, Altman menyusun 22 rasio keuangan yang paling memungkinkan dan mengelompokkannya dalam 5 kategori: likuiditas, profitabilitas, leverage, solvabilitas dan kinerja. Lima macam rasio dari lima variabel yang terseleksi akan dikombinasikan bersama untuk memperoleh prediksi yang paling akurat tentang kebangkrutan.
\end{abstract}

Kata kunci: Altman Z-score, prediksi potensi kebangkrutan.

\section{Pendahuluan.}

Dampak krisis awal Juli 1997, terjadi gejolak nilai tukar. Bersamaan dengan itu, pemerintah melakukan pengetatan likuiditas. Kondisi ini memunculkan krisis kepercayaan masyarakat terhadap perbankan nasional, terutama pasca pencabutan ijin usaha 16 bank pada tanggal 1 November 1997. Hal ini berdampak sangat buruk, terutama memicu terjadinya depresiasi kepercayaan terhadap perbankan. Sebagai manifestasi krisis kepercayaan itu, terjadi penarikan dana secara besar-besaran. Akibatnya, banyak bank yang mengalami kesulitan likuiditas yang sangat parah (mismatch) yang disusul dengan kelangkaan likuiditas perekonomian secara keseluruhan (liquidity crunch). Keadaan semakin diperparah dengan melambungnya suku bunga Pasar Uang Antar Bank (PUAB) hingga mencapai 300\% per tahun.

Keputusan likuidasi 16 bank pada tanggal 1 November 1997 dianggap sebagai pemicu krisis kepercayaan yang berlanjut dengan terpuruknya sektor perbankan. Sebenarnya, tindakan likuidasi itu diambil untuk mencegah semakin meluasnya krisis perbankan (system risk) dan besarnya risiko yang ditanggung masyarakat (economic 
cost). Selain itu, keputusan likuidasi juga merupakan hasil evaluasi dan rekomendasi IMF yang dituangkan ke dalam Letter of Intent (LOI) antara pemerintah dengan IMF pada tanggal 31 Oktober 1997. Kesepakatan dengan IMF ini yang juga merupakan tahapan awal pelaksanaan reformasi ekonomi dan perbankan yang tertuang dalam Memorandum of Economic and Financial Policies yang ditandatangani pada awal November 1997. Program reformasi tersebut juga telah mendapat dukungan teknis dan keuangan dari Bank Dunia, Bank Pembangunan Asia, dan negara-negara sahabat lainnya. Namun, upaya yang semula dimaksudkan untuk memulihkan kepercayaan kepada perbankan itu ternyata oleh masyarakat ditanggapi secara negatif. Masyarakat melakukan penarikan dan pengalihan dana secara besar-besaran (bank run), sehingga sejumlah bank mengalami mismatch dan terus mengalami saldo negatif (saldo debet) pada gironya di Bank Indonesia.

Terkait arah kebijakan 1997-1999, dengan perubahan UU No. 7 Tahun 1992 tentang Pokok Pokok Perbankan menjadi UU No. 10 Tahun 1998 tentang perbankan, peranan Bank Indonesia dalam kebijakan perbankan mengalami perubahan yang drastis. Perubahan tersebut antara lain mengatur :

(1) pengalihan wewenang perizinan di bidang perbankan dari Menteri Keuangan kepada Pimpinan Bank Indonesia.

(2) pemilikan bank oleh pihak asing tidak dibatasi tetapi tetap memperhatikan prinsip kemitraan.

(3) Pengembangan bank berdasarkan syariah

(4) Perubahan cakupan rahasia bank yang semula meliputi sisi aktiva dan pasiva dari neraca bank, menjadi nasabah penyimpan dan simpanannya.

(5) Pembentukan lembaga penjamin simpanan (LPS) dan

(6) Pendirian badan khusus yang bersifat sementara dalam rangka penyehatan perbankan.

Dampak krisis perbankan nasional terhadap luar negeri akhirnya dapat diatasi dengan berbagai kesepakatan, antara lain :

1. Letter of Credit $(L / C)$ yang diterbitkan oleh bank-bank nasional yang tidak dapat di terima di luar negeri, dijamin secara tunai oleh Bank Indonesia.

2. Hutang bank-bank kepada kreditur luar negeri disepakati untuk direschedul (jadwal ulang).

Langkah-langkah Strategis 1997-1999, dalam masa krisis, peran Bank Indonesia tidak dapat digambarkan sebagai peran yang berdiri sendiri, tetapi merupakan bagian integral dari upaya Indonesia untuk menanggulangi permasalahan negara. Selama krisis berlangsung, penyelamatan sistem perbankan nasional dilakukan dalam intensitas tinggi. Koordinasi dengan pemerintah dilakukan melalui berbagai forum, antara lain sidang kabinet terbatas bidang Ekkuwasbang dan Prodis tanggal 3 September 1997, pencabutan izin usaha 16 bank tanggal 1 November 1997, penerapan program penjaminan pemerintah tanggal 26 Januari 1998, pendirian BPPN tanggal 26 Januari 1998, identifikasi bank-bank berdasarkan kriteria rekapitalisasi pada akhir 1998, pengambilan bank-bank oleh pemerintah pada bulan Mei 1998 dan pembekuan operasional bank pada bulan Mei dan Agustus 1998 serta penghentian 
kegiatan usaha tertentu bank-bank tanggal 13 Maret 1999. Menghadapi masalah perekonomian yang makin meluas maka pemerintah meminta bantuan kepada Dana Moneter Internasional (International Monetary Fund-IMF). Kesepakatan antara Pemerintah dan IMF bertalian dengan upaya mengatasi krisis dan restrukturisasi perbankan tertuang dalam Memorandum on Economic and Financial Policies yang mencakup rencana aspek ekonomi yang menyeluruh. Di sektor perbankan pembenaham perbankan menyangkut langkah-langkah penutupan bank tidak solven dan restrukturisasi terhadap bank-bank lain. Bank-bank yang mengalami masalah di bagi menjadi dua kelompok, yaitu kelompok bank yang perlu direkapitalisasi dan kelompok bank yang memerlukan pengawasan lebih intensif, perwalian, atau pengambilalihan bank.

Selanjutnya Otoritas pengawasan 1997-1999, dengan amandemen UU No. 7 Tahun 1992 tentang Pokok-pokok perbankan menjadi UU No. 10 Tahun 1998 tentang Perbankan maka wewenang perizinan di bidang perbankan beralih dari Menteri Keuangan Kepada Pimpinan Bank Indonesia. Sebagai otoritas pengawasan bank, dalam masa krisis itu Bank Indonesia menjalankan wewenangnya untuk mengatasi kesulitan yang membahayakan kelangsungan usaha bank. Sesuai dengan UU No. 7 Tahun 1992 tentang Perbankan, terdapat enam tindakan yang dapat dilakukann Bank Indonesia, yaitu:

1) Pemegang saham diminta untuk menambah modal,

2) Pemegang saham diminta untuk mengganti dewan komisaris dan atau direksi bank,

3) Bank diminta untuk menghapus bukukan kredit yang macet dan memperhitungkan kerugian bank dengan modal

4) Bank diminta untuk melakukan merger atau konsolidasi dengan bank lain,

5) Bank diminta untuk dijual kepada pembeli yang bersedia mengambil alih seluruh kewajiban bank, dan

6) Bank Indonesia mengambil tindakan lain sesuai dengan peraturan perundangan yang berlaku. Apabila tindakan di atas tidak berhasil untuk menyelesaikan masalah yang dihadapi oleh bank, maka Bank Indonesia dapat mencabut izin usaha bank yang bersangkutan.

Selanjutnya, Sasaran Strategis 1997-1999, krisis nilai tukar yang menyerang Indonesia pada pertengahan tahun 1997 memicu terjadinya krisis perbankan. Pada periode ini fungsi pengawasan bank dititikberatkan pada program penyehatan perbankan serta program untuk meningkatkan ketahanan perbankan. Penyehatan perbankan dilakukan meliputi program penjaminan, program reapitalisasi perbankan dan restrukturisasi kredit. Sedangkan upaya peningkatan ketahanan perbankan dilakukan melalui perbaikan infrastruktur perbankan, peningkatan mutu pengelolaan bank, penyempurnaan ketentuan perbankan dan pemantapan sistem pengawasan bank. Pada periode ini pengawasan yang dilakukan oleh BPK juga dilakukan untuk mengawasi penggunaan obligasi pemerintah dalam rangka rekapitalisasi perbankan. 
Kajian Pustaka.

Kajian Terdahulu.

Amin Jan and Maran (2015) dalam penelitiannya yang berjudul: "Bankruptcy and Sustainability" A Conceptual Review on Islamic Banking Industry, Global Business and Management Research: An International Journal Vol.7. No.1.2015, Design/methodology/approach: Concluding that; This study first described the share of Islamic banking industry along with conventional banking industry share in major Muslim countries, whereas the share of Islamic banking industry is recorded very low as compared to conventional banking share. Secondly, the study explored the significant decline in Islamic banking industry through major key performance indicators along with the country wise decrease in Assets CAGR. The point of attention here is that, the banking industry holds a vital position inside any economy and the dependency of efficient financial system is ever more dependent on the proper working of banking industries and vice versa. More importantly, the identified deterioration in major KPI's of Islamic banking industry can lead to the collapse of financial system especially in those Islamic banking countries where the dominance of Islamic banking industry in the economy is very high.

Pada volume berikutnya, Amin Jan \& Maran Marimuthu (2015), Department of Management and Humanities, Universiti Teknologi Petronas, Malaysia dalam peneltiannya yang berjudul: "Altman Model and Bankruptcy Profile of Islamic Banking Industry: A Comparative Analysis on Financial Performance, International Journal of Business and Management: Vol.10 No.7.April 23,2015, Published by Canadian Center of Science and Education, Concluding that; The study applied Altman bankruptcy model, and post ANOVA post hoc Scheffe test on 25 selected Islamic banks from top five Islamic banking countries by global Islamic banking-assets. In response to the first objective of the study, the comparative analysis of Z-score results in Table 4 illuminated that, on average the Islamic banking industry of Saudi Arabia performance better than the rest of the sample as Saudi's banks reserved $1^{\text {st }}$ and $2^{\text {nd }}$ spots on Z-score bankruptcy ranking list. Following Saudi Arabia the performance of by Iranian Islamic banks found better on average, as its banks reserved the $3 \mathrm{rd}$ and 5 th spots in Z-score bankruptcy list as well.

Selanjutnya diteruskan Amin Jan, Maran Marimuthu (2016) dalam penelitiannya yang berjudul;" Bankruptcy Profile of Foreign versus Domestic Islamic Banks of Malaysia: A Post Crisis Period Analysis, International Journal of Economics and Financial Issues: For saturating the first objective of the study i.e., is to examine the bankruptcy rate of foreign and domestic Islamic banks of Malaysia, this study categorized the financial performance of Islamic banks into three zones i.e., the safe zone, the grey zone and the bankruptcy zone using Altman model. The sample of foreign Islamic banks found $40 \%$ in the bankruptcy zone, $40 \%$ in the grey zone and just $20 \%$ in the safe zone. On the other hand, the sample of domestic Islamic banking found $75 \%$ in the bankruptcy zone, $00 \%$ in the grey zone and just $25 \%$ in the safe zone. The ANOVA result uncovered that, the foreign and domestic 
Islamic banks of Malaysia do differ on bankruptcy zone and grey zones. However, the sample of foreign and domestic Islamic banks of Malaysia do not differ on the financial characteristics of the safe zone. In the line of identified bankruptcy rates i.e., $75 \%$ by domestic and $40 \%$ by the sample of foreign Islamic bank, it is anticipated that the sample of foreign Islamic banks of Malaysia is more sustainable.

Mahmoud Sami Nabi (2012), dalam penelitiannya yang berjudul; "Dual Banking and Financial Contagion" Vol.20, No.2, Desember 2012, to conclusion The share of Islamic banks in the banking system of many countries is growing. This transformation generated new challenges for the design of regulatory and supervisory frameworks by central banks and motivated many research studies aiming to compare the behavior of IBs relatively to CBs. This paper shed light on the optimal behavior of an IB when bankruptcy occurs in the conventional banking sector.

Saijad Zaheer (University of Amsterdam), Moazzam Farooq (2014) dalam penelitiannya yang berjudul;" Liquidity Crisis: Are Islamic Banking Institutions More Resilient? To Conclusion, The impotance of liquidity risk and the threat of ensuing bank-run cannot be overemphasized. The peculiar structure of Islamic banks and their call to the faith of the customers pose onteresting questions regarding their behavior during a liquidity crisis and calls for detailed empirical study. Using a natural experiment from Pakistan we attempt to fill this gap and decipher the differential behavior of Islamic and conventional banking institutions during the episodes of liquidity crunch. Our results show that, Islamic banking branches are less prone to the risk of withdrawal during the bouts of liquidity stress and this effect remains there after introducing an array of controls.

Smart C.Gilson (The University of Texas of Austin, USA), Received September 1989, final version received July 1990 yang berjudul: Bankruptcy, boards, banks and blockholders, Conclusions : This paper investigates changes in corporate ownership and control in firms that default on their debt. For a sample of 111 publicly traded firms that either went bankrupt or privately restructured their debt, I find evidence consistent with a shift in control over corporate resources from incumbent management and the board of directors towards nonmanagement blockholders and creditors. On average, only $46 \%$ of incumbent directors and $43 \%$ of CEOs remain with their firms at the conclusion of the bankcruptcy or debt restructuring. Directors who resign from financially distressed firms subsequently serve on fewer boards of other companies. Over

P.Merchant dalam penelitiannya yang berjudul: Empirical Study of Islamic Banks Versus Conventional Banks of GCC, University School of Management, Conclusion: Our analysis shows that during the four year period of 2008-2011, EQTA, ROAE and COSR were found be significant. While Islamic banks were found to deliver high in terms of EQTA, conventional banks were found to perform well in ROAE and COSR. This indicates that over the four year, Islamic banks were better capitalized but have performed low in terms of profitability. COSR as an indicator of management efficiency was found to be poor for Islamic banks. Consistent high COSR has led to low profitability levels of Islamic banks after the crisis. 
Ascarya (2015) dalam penelitiannya menemukan bahwa terdapat 3 penyebab umum yang dominan dari krisis keuangan, yakni: ketidakstabilan sistem moneter $(24,8 \%)$, Tata Kelola yang buruk $(20,5 \%)$, dan kelakuan buruk agen ekonomi $(19,7 \%)$. Sementara itu, penyebab detail yang dominan dari krisis keuangan itu ada 7 yaitu: faktor eksternal-ketidak stabilan sosial (4,87\%), faktor fiskal-hutang yang berlebihan $(4,74 \%)$, faktor eksternal-ketidak stabilan politik (4,63\%), faktor perilakuspekulan $(4,56 \%)$, faktor moneter-sistem bunga $(3,94 \%)$, faktor tata kelola-korupsi $(4,46 \%)$ dan faktor perilaku-keserakahan agen-agen ekonomi $(4,12 \%)$.

Beaver (1996) membuktikan bahwa secara empiris rasio keuangan dapat digunakan sebagai alat prediksi kegagalan perusahaan. Meskipun tidak semua rasio dapat memprediksi dengan sama baiknya dan tidak dapat memprediksi dengan tingkat keberhasilan yang sama. Beliau menggunakan Univariate Analysis dan mempertemukan sampel perusahaan yang gagal dengan yang tidak gagal, kemudian meneliti rasio keuangan selama lima tahun sebelum perusahaan gagal. Pada perusahaan yang gagal cash flow to total debt lebih rendah, cadangan aktiva lancar untuk melunasi kewajibannya lebih kecil dan hutangnya lebih besar dibandingkan perusahaan yang tidak gagal.

Synkey (1995) dalam penelitiannya tentang manfaat rasio keuangan dalam memprediksi kondisi keuangan bank dengan menggunakan multiple discriminant analysis dalam menguji perusahaan bank yang bermasalah, dengan sepuluh rasio keuangan dalam menguji sampel sebanyak 110 perusahaan perbankan. Sinkey menemukan bahwa rasio keuangan signifikan berbeda antara perusahaan perbankan bermasalah dengan perusahaan perbankan yang tidak bermasalah untuk periode 4 tahun sebelum bank mengalami masalah. Hasil penelitian ini menunjukkan bahwa bank yang bermasalah kurang efisien dalam operasionalnya, kecukupan modal yang diukur dengan loan to capital kurang memadai dan rasio likuiditas lebih rendah dibandingkan bank yang tidak bermasalah.

Thomson (1991) menguji manfaat rasio keuangan dalam memprediksi kebangkrutan perusahaan bank. Thomson menggunakan logit regression untuk menganalisis sampel sebanyak 1.736 perusahaan tidak bangkrut dan 770 perusahaan bangkrut selama periode 1984 sampai dengan 1988. Thomson menyimpulkan bahwa kemungkinan perusahaan bank akan bangkrut adalah fungsi dan variabel yang berkaitan dengan solvency termasuk rasio CAMEL( Capital, Assets, Management, Earning, Liquidity) yang dimilikinya.Thomson juga menemukan bahwa rasio CAMEL sebagai proxy variabel kondisi keuangan bank merupakan faktor signifikan yang berkaitan dengan kemungkinan kebangkrutan bank untuk periode 4 tahun sebelum perusahaan bank bangkrut.

Altman (1998) menguji manfaat rasio keuangan dalam memprediksi kebangkrutan. Altman menggunakan sampel sebanyak 66 perusahaan yang terdiri atas 33 perusahaan bangkrut dan 33 perusahaan tidak bangkrut. Altman menggunakan Multivariate Discriminant Analysis dalam menguji manfaat lima rasio keuangan dalam memprediksi kebangkrutan yaitu: working capital to total assets, retained earning to total assets, earning before interestand tax to total assets, market value 
equity to book value of debt and sale to total assets. Hasil analisa menunjukkan bahwa rasio keuangan (profitability, liquidity dan solvency) bermanfaat dalam memprediksi kebangkrutan dengan tingkat keakuratan $95 \%$ setahun perusahaan bangkrut. Tingkat keakuratan tersebut turun menjadi $72 \%$ untuk periode dua tahun sebelum bangkrut, $48 \%$ untuk periode tiga tahun sebelum bangkrut, 36\% untuk periode empat tahun sebelum bangkrut dan $20 \%$ untuk periode lima tahun sebelum bangkrut.

Machfoedz (1999) melakukan penelitian dengan menggunakan pendekatan Altman untuk menganalisis tingkat kesehatan perusahaan untuk memprediksi potensi kebangkrutan perusahaan. Sampel yang digunakan dibagi dalam dua kelompok perusahaan perbankan dan non perbankan dengan working capital to total assets, retained earning to total assets, earning before interest and tax to total assets, market value equity to book value of debt and sales to total assets. Hasil analisis dalam penelitian ini menunjukkan bahwa analisis tingkat kesehatan pada perusahaan perbankan dan non perbankan menunjukkan kondisi kinerja yang tidak sehat. Demikian pula pada hasil analisis potensi kebangkrutan yang menunjukkan hasil ZScore yang sangat rendah. Hal ini menunjukkan bahwa antara rasio-rasio dalam tingkat kesehatan dengan rasio-rasio dalam potensi kebangkrutan mempunyai hubungan yang sangat kuat dalam menentukan kondisi keuangan perusahaan tersebut. Tingkat kesehatan keuangan bisa juga digunakan sebagai alat ukur yang pertama untuk menunjukkan kondisi keuangan perusahaan, dan untuk lebih meyakinkan kondisi kebangkrutan bisa digunakan untuk memprediksi potensi kebangkrutan. Dengan demikian formula yang ditemukan Altman bisa digunakan sebagai salah satu alat ukur yang handal untuk memprediksi kebangkrutan sebuah perusahaan.

\section{A. Teori dasar (Grand Theory) atas kinerja perbankan.}

\section{Analisis Makroekonomi (Macroeconomy analysis).}

Makroekonomi menjadi teori dasar dalam penulisan proposal ini yang membahas isu-isu penting dan selalu dihadapi dalam penentuan kegiatan ekonomi. Analisis mengenai penentuan tingkat kegiatan yang dicapai suatu perekonomian merupakan bagian penting dari analisis makroekonomi, termasuk didalamnya kegiatan perbankan. Analisis tersebut menunjukkan bagaimana pengeluaran dan penawaran agregat akan menentukan tingkat keseimbangan kegiatan sesuatu perekonomian.

\section{Teori keagensi (Agency Theory).}

Grand teori penelitian ini menggunakan teori keagensi (agency theory) dan teori signal (signalling theory). Teori keagensi menjelaskan bahwa pada sebuah prusahaan terdapat dua pihak yang saling berinteraksi yaitu pemilik perusahaan sebagai principal dan pihak manajemen perusahaan yang diberi kewenangan oleh pemegang saham untuk menjalankan perusahaan sebagai agen. Prinsip utamanya menunjukkan adanya hubungan kerja antara pihak yang memberi wewenang dengan 
pihak yang menerima wewenang dalam bentuk kontrak kerja sama (Elqorni, 2009 dalam Primasari, 2011). Masalah keagenan muncul karena terdapat konflik perbedaan pendapat (kepentingan) antara pemilik dengan manajemen (Siallagan dan Machfoedz, 2006).

\section{Teori Signal (Signalling Theory).}

Menurut Brigham dan Hauston isyarat atau signal adalah suatu tindakan yang diambil perusahaan untuk memberi petunjuk bagi investor tentang bagaimana manajemen memandang prospek perusahaan. Sinyal ini berupa informasi mengenai apa yang sudah dilakukan oleh manajemen untuk merealisasikan keinginan pemilik. Informasi yang dikeluarkan oleh perusahaan merupakan hal yang penting, karena pengaruhnya terhadap keputusan investasi pihak di luar perusahaan. Informasi tersebut penting bagi investor dan pelaku bisnis karena informasi pada hakekatnya menyajikan keterangan, catatan atau gambaran, baik untuk keadaan masa lalu, saat ini maupun masa yang akan datang bagi kelangsungan hidup perusahaan dan bagaimana efeknya pada perusahaan.7)

Menurut Sari dan Zuhrotun (2006), teori signal menjelaskan mengapa perusahaan mempunyai dorongan untuk memberikan informasi laporan keuangan kepada pihak eksternal, hal ini timbul karena adanya informasi asimetris antara perusahaan dengan pihak luar, dimana manajemen mengetahui informasi internal yang relatif lebih banyak dan lebih cepat dibandingkan pihak luar seperti investor dan kreditur.

Laporan keuangan merupakan ikhtisar mengenai keadaan keuangan suatu perusahaan pada suatu periode tertentu. Dalam rangka peningkatan transparansi kondisi keuangan, berdasarkan peraturan Bank Indonesia Nomor 3/22/PBI/2001 tanggal 13 Desember 2001, bank wajib menyusun dan menyajikan laporan keuangan dalam bentuk dan cakupan yang terdiri dari (Siamat, 2005) :

\section{Teori Kontijensi (Contingency Theory).}

Kontijensi (contingency) adalah suatu keadaan atau situasi yang diperkirakan akan segera terjadi tetapi mungkin juga tidak akan terjadi. Pendekatan kontijensi pada akuntansi manajemen didasarkan pada premis bahwa tidak ada sistem akuntansi manajemen secara universal selalu tepat untuk bisa diterapkan pada seluruh organisasi dalam setiap keadaan, tetapi sistem akuntansi manajemen tergantung juga pada faktor-faktor situasional yang ada dalam organisasi. Hasil peneltian-penelitian sebelumnya menunjukkan adanya ketidak konsistenan antara penelitian satu dengan penelitian lainnya., yang terjadi karena kemungkinan adanya variabel lain yang mempengaruhi hubungan antara model prediksi kebangkrutan dengan pemberian opini going concern. 


\section{Teori harapan (Expactancy Theory).}

Menurut Victor Vroom (1964), menyatakan bahwa kekuatan dari suatu kecendrungan untuk bertindak dalam cara tertentu bergantung pada kekuatan dari suatu harapan bahwa tindakan tersebut akan diikuti dengan hasil yang ada pada daya tarik dari hasil ini terhadap variabel tersebut.

Harapan merupakan kesempatan yang diberikan terjadi karena perilaku, nilai yang merupakan akibat dari perilaku tertentu atau martabat tertentu bagi setiao individu tertentu, serta pertautan (instrumentality) yang merupakan persepsi dari individu bahwa hasil dari tingkat pertama akan dihubungkan dengan hasil tingkat kedua. Selanjutnya opini going concern harus diungkapkan dengan harapan dapat segera mempercepat usaha penyelamatan perusahaan yang bermasalah (Joanna, 1994). Apabila auditor salah memberikan opini kepada perusahaan yang diaudit maka akan menjadi masalah yang lebih besar di masa yang akan datang seperti misalnya kondisi perusahaan yang akan semakin memburuk akibat salah opini. Dan auditor yang memberikan opini secara langsung maupun tidak merupakan pihak yang juga ikut bertanggung jawab.

\section{Human Judgement Theory (HJT).}

Human judgment theory menjelaskan bagaimana cara orang-orang menggunakan dan memproses informasi akuntansi terhadap suatu fakta dalam konteks pengambilan keputusan. Tujuan dari penelitian dalam model ini lebih menjelaskan dan memprediksi perilaku pada individu atau grup. Hal ini juga berkaitan dengan meningkatkan kualitas pengambilan keputusan. Penelitian H JT memiliki dasarnya dalam literature psikologi dari Ward Edwards pada tahun 1954 (Godfrey, Jayne et al. 2010)

\section{Kebangkrutan dalam Hukum Positif.}

Menurut Ensiklopedi Indonesia, kepailitan didefinisikan sebagai ketidakmampuan pihak penghutang atau debitur (bisa orang, badan hukum, perseroan) yang terbukti berdasarkan ketetapan pengadilan, bahwa debitur telah berhenti membayar hutangnya(tidak mampu melunasi hutang) yang mengakibatkan penyitaan umum atas harta kekayaannya, sehingga debitur tidak berhak lagi mengurus harta bendanya. Dalam hukum perdata (peraturan kepailitan: S.1905-217 jo S.1906-438) kata pailit mengacu kepada keadaan debitur yang terbukti berdasarkan ketetapan pengadilan, bahwa debitur telah berhenti membayar hutaangnya (tidak mampu melunasi hutaang) yang mengakibatkan penyitaan umum atas harta kekayaannya, sehingga debitur tidak berhak lagi mengurus harta bendanya.

Pada pasal 1 butir1 UU No.37 Tahun 2004 Tentang Kepailitan dan penundaan kewajiban pembayaran utang berbunyi: "Kebangkrutan adalah sita umum atas semua kekayaan Debitor pailit yang pengurusan dan pemberesannya dilakukan oleh curator di bawah pengawasan hakim pengawas sebagaimana diatur Undang-Undang". 
Pengertian kepailitan mengacu kepada Peraturan Pemerintah pengganti UU Nomor 1 tahun 1998 tentang perubahan atas UU kepailitan yang menyebutkan: a) Debitur yang mempunyai 2(dua) atau lebih kreditur dan tidak membayar sedikitnya satu utang yang jatuh tempo dan tidak dapat ditagih, dinyatakan pailit dengan putusan pengadilan yang berwenang, baik atas permohonannya sendiri, maupun atas permintaan seorang atau lebih krediturnya. b) Permohonan sebagaimana disebut dalam butir diatas, dapat juga diajukan oleh kejaksaan untuk kepentingan umum. Undang-Undang kepailitan menyatakan bagaimana menyeleseikan sengketa yang muncul dikala satu perusahaan tidak bisa lagi memenuhi kewajiban utang, juga bagaimana menangani pertikaian antar individu yang berkaitan dengan usaha dan bisnis yang dijalankan. Perusahaan bisa dinyatakan pailit/bangkrut apabila dalam jangka waktu tertentu tidak bisa melakukan pembayaran pokok atau bunganya. Kepailitan juga bisa diminta oleh pemilik perusahaan atau juga oleh para penagih utang. Kebangkrutan dapat diartikan sebagai kegagalan perusahaan dakam menjalankan operasi perusahaan untuk menghasilkan laba. ${ }^{18)}$ Menurut Hanafi (2009): kebangkrutan merupakan kesulitan keuangan jangka pendek bersifat sementara dan belum begitu parah. Menurut Toto (2011): kebangkrutan (bankruptcy) merupakan kondisi dimana perusahaan tidak mampu lagi untuk melunasi kewajibannya. Brigham (2012): kebangkrutan adalah suatu kegagalan ekonomi (economic distressed), merupakan kondisi perusahaan kehilangan uang atau pendapatan, perusahaan tidak mampu menutupi biayanya sendiri, artinya tingkat labanya lebih kecil dari biaya modal atau nilai sekarang dari arus kas perusahaan lebih kecil dari kewajiban. Kegagalan terjadi bila arus kas sebenarnya dari perusahaan tersebut jauh di bawah arus kas yang diharapkan. Kedua adalah kegagalan keuangan (financial distressed), merupakan kondisi perusahaan yang mana kesulitan dana baik dalam arti dana didalam pengertian kas atau dalam pengertian modal kerja. Kebangkrutan diartikan sebagai kegagalan keuangan atau financial failure dan kegagalan ekonomi atau economic failure (Adnan dan Kurniasih, 2008; 137).

\section{Pengertian potensi kebangkrutan.}

Potensi berasal dari bahasa Latin yang artinya kemampuan yang mempunyai kmungkinan untuk dikembangkan (Ensiklopedia). Potensi adalah kemampuan, kekuatan, kesanggupan, daya yang mempunyai kemungkina untuk dikembangkan (Kamus Besar). Kebangkrutan dapat diartikan sebagai kegagalan perusahaan dalam menjalankan operasi perusahaan untuk menghasilkan laba. ${ }^{10}$ Menurut Hanafi (2009), kebangkrutan merupakan kesulitan keuangan jangka pendek bersifat sementara dan belum begitu parah. Menurut Toto (2011), kebangkrutan (bankruptcy) merupakan kondisi dimana perusahaan tidak mampu lagi untuk melunasi kewajibannya. Menurut Brigham (2012), kebangkrutan adalah suatu kegagalan ekonomi (Economic Distressed), merupakan kondisi perusahaan kehilangan uang atau pendapatan perusahaan tidak mampu menutupi biayanya sendiri, artinya tingkat labanya lebih kecil dari biaya modal atau nilai sekarang dari arus kas perusahaan lebih kecil dari kewajiban. Kegagalan terjadi bila arus kas sebenarnya dari arus kas perusahaan lebih 
kecil dari kewajiban. Kegagalan terjadi apabila arus kas sebenarnya dari perusahaan tersebut jauh di bawah arus kas yang diharapkan. Kedua adalah kegagalan keuangan (financial distressed), merupakan kondisi perusahaan yang mana kesulitan dana baik dalam arti dana didalam pengertian kas atau dalam pengertian modal kerja. Kebangkrutan diartikan sebagai kegagalan keuangan atau financial failure dan kegagalan ekonomi atau economic failure (Adnan dan Kurniasih, 2008; 137).

\section{Faktor-faktor Penyebab Kebangkrutan.}

Menurut Jauch dan Glueck (1995:87): secara garis besar faktor penyebab kebangkrutan dibagi menjadi tiga bagian: a. Faktor umum meliputi: 1) Sektor ekonomi yang terdiri (gejala inflasi dan deflasi dalam harga barang dan jasa, kebijakan keuangan, suku bunga, dan devalusi atau revaluasi uang dalam hubungannya dengan uang asing, serta neraca pembayaran surplus atau defisit dalam hubungannya dengan perdagangan luar negeri. 2) Sektor sosial yaitu, perubahan gaya hidup masyarakat yang mempengaruhi permintaan terhadap produk dan jasa ataupun cara perusahaan berhubungan dengan karyawan, kerusuhan atau kekacauan yang terjadi di masyarakat. 3) Sektor teknologi yaitu, penggunaan teknologi informasi menyebabkan biaya yang dikeluarkan oleh perusahaan menjadi lebih besar terutama untuk pemeliharaan dan implementasi. 4) Sektor pemerintah yaitu, adanya kebijakan pemerintah terhadap pencabutan subsidi pada perusahaan dan industri, pengenaan tarif ekspor dan impor barang yang berubah, kebijakan Undang-Undang baru perbankan atau tenaga kerja juga dapat menjadi penyebab kebangkrutan. b. Faktor eksternal perusahaan meliputi: 1) Sektor pelanggan yaitu, perusahaan harus dapat mempertahankan konsumennya dan mencegah konsumen berpaling ke pesaing, sekaligus menciptakan peluang untuk menemukan konsumen baru agar dapat menghindari menurunnya hasil penjualan yang akan mengakibatkan menurunnya pendapatan perusahaan. 2) Sektor pemasok yaitu, hubungan kerja sama antara pemasok dengan perusahaan sangat penting karena kekuatan pemasok untuk menaikkan harga dan mengurangi keuntungan pembelinya tergantung pada seberapa jauh pemasok ini berhubungan dengan pedagang bebas. 3).Sektor pesaing yaitu, produk pesaing yang lebih diterima masyarakat menyebabkan perusahaan kehilangan konsumen sehingga mengurangi pendapatan yang seharusnya diterima. c.Faktor internal perusahaan yang meliputi: 1).Terlalu besarnya kredit yang diberikan kepada debitur/pelanggan yaitu, hal ini menjadi faktor penyebab kebangkrutan terutama jika debitur atau pelanggan tidak dapat membayar jumlah kredit yang diberikan oleh perusahaan pada waktunya. 2).Manajemen yang tidak efisien yaitu, kurang adanya kemampuan,pengalaman, eterampilan, sikap adaptif dan inisiatif dari manajemen dapat pula menyebabkan kebangkrutan bagi suatu perusahaan. 3).Penyalahgunaan wewenang dan kecurangan-kecurangan yaitu, penyalahgunaan wewenang sangat merugikan perusahaan apalagi bila berhubungan dengan keuangan perusahaan. 


\section{Indikator Terjadinya Kebangkrutan.}

Indikator-indikator yang menandai perusahaan akan mengalami kebangkrutan:

a. Volume penjulan yang relatif rendah atau adanya tren penjualan yang menurun.

b. Cash flow yang negatif.

c. Kerugian yang selalu diderita oleh operasinya.

d. Utang yang selalu membengkak.

Menurut Teng (2002:13) tanda-tanda paling jelas akan datangnya kegagalan sebuah perusahaan adalah sebagai berikut: a). Profitabilitas yang negative/menurun. b). Merosotnya posisi pasar. c). Posisi kas yang buruk/negative/ ketidakmampuan melunasi kewajiban-kewajiban kas. d). Tingginya perputaraan karyawan/ rendahnya moral. e). Penurunan volume penjualan. f).Penurunan nilai penjualan. g). Ketergantungan terhadap utang. h).Kerugian yang selalu diderita dari operasinya.

\section{Prediksi Kebangkrutan dengan Model Altman (Z-Score).}

Altman (1968) adalah orang yang pertama menerapkan Multiple Discrimnant Analysis. Analisa diskriminan ini merupakan suatu teknik statistik yang mengidentifikasikan beberapa macam rasio keuangan yang dianggap memiliki nilai paling penting dalam mempengaruhi suatu kejadian, lalu mengembangkannya dalam suatu model dengan maksud untuk memudahkan menarik kesimpulan dari suatu kejadian. Analisa diskriminan ini kemudian menghasilkan satu dari beberapa pengelompokam yang bersifat apriori atau mendasarkan teori dari kenyataan yang sebenarnya. Dasar pemikiran Altman menggunakan analisa diskriminan bermula dari keterbatasan analisa rasio yaitu metodologinya pada dasarnya bersifat suatu penyimpangan yang artinya setiap rasio diuji secara terpisah sehingga pengaruh kombinasi dari beberapa rasio hanya didasarkan pada pertimbangan para analisa keuangan. Oleh karena itu untuk mengatasi kekurangan dari analisa rasio maka perlu dikombinasikan berbagai rasio agar menjadi suatu model prediksi yang berarti.

Dengan berdasarkan penelitian analisa diskriminan, Altman melakukan penelitian untuk mengembangkan model baru untuk memprediksikan kebangkrutan perusahaan. Model yang dinamakan Z-Score dalam bentuk aslinya adalah model linier dengan rasio keuangan yang diberi bobot untuk memaksimalkan kemampuan model tersebut dalam memprediksi. Model "Z" yaitu nilai yang menunjukkan kondisi perusahaan, apakah dalam keadaan sehat atau tidak dan menunjukkan kinerja perusahaan yang sekaligus merefleksikan prospek perusahaan dimasa mendatang. Dalam menyusun model, Z-Altman mengambil sampel 33 perusahaan manufaktur yang bangkrut pada periode 1960 sampai 1965 dan 33 perusahaan yang tidak bangkrut dengan lini industry dan ukuran yang sama. Dengan menggunakan data laporan keuangan dari 1 sampai 5 tahun sebelum kebangkrutan, Altman menyusun 22 rasio keuangan yang paling memungkinkan dan mengelompokkannya dalam 5 kategori: likuiditas, profitabilitas, leverage, solvabilitas dan kinerja. Lima macam rasio dari lima variabel yang terseleksi akan dikombinasikan bersama untuk memperoleh prediksi yang paling akurat tentang kebangkrutan. 
Penggunaan model Altman sebagai salah satu pengukuran kinerja kebangkrutan tidak bersifat tetap atau stagnan melainkan berkembang dari waktu ke waktu, dimana pengujian dan penemuan model terus diperluas oleh Altman hingga penerapannya tidak hanya pada perusahaan manufaktur public saja tapi sudah mencakup perusahaan manufaktur non public, perusahaan non manufaktur, dan perusahaan obligasi korporasi.

Prediksi kebangkrutan yang diformulasikan oleh Altman (1994) dengan bentuk persamaan yang kemudian dikenal dengan formulasi Z-Score:

$\mathrm{Z}=\mathrm{W}_{1} \mathrm{X}_{1}+\mathrm{W}_{2} \mathrm{X}_{2}+\mathrm{W}_{3} \mathrm{X}_{3}+\mathrm{W}_{4} \mathrm{X}_{4}+\mathrm{W}_{5} \mathrm{X}_{5}$

Formula Z-Score merupakan kombinasi dari beberapa rasio keuangan yang dianggap dapat memprediksi terjadinya kebangkrutan pada sebuah perusahaan . Rasio-rasio tersebut merupakan rasio-rasio yang mendeteksi kondisi keuangan perusahaan yang berkaitan dengan: Likuiditas, Profitabilitas dan aktivitas perusahaan. Adapun rasio-rasio tersebut terdiri dari:

$\mathrm{X}_{1}=$ Working Capita / Total Assets.

$\mathrm{X}_{2}=$ Retained Earning/Total Assets.

$\mathrm{X}_{3}=$ EarnignBefore Interest and Taxes/Total Assets.

$\mathrm{X}_{4}=$ Market value of Equity/ Book Value of Total Debt.

$\mathrm{X}_{5}=$ Sales $/$ Total Assets.

Kelima rasio inilah yang akan digunakan dalam menganalisa laporan keuangan sebuah perusahaan untuk kemudian mendeteksi kemungkinan terjadinya kebangkrutan pada perusahaan tersebut. Dalam menajemen keuangan, rasio -rasio yang digunakan dalam metode altman ini dapat dikelompokkan dalam 3 kelompok besar yaitu:

1.Rasio likuiditas yang terdiri $\mathrm{X}_{1}$

2.Rasio profitabilitas yang terdiri dari $\mathrm{X}_{2}$ dan $\mathrm{X}_{3}$

3.Rasio aktivitas yang terdiri dari $\mathrm{X}_{4}$ dan $\mathrm{X}_{5}$. (Riyanto, 2001:330)

\section{Jenis dan Sumber Data.}

Dalam penelitian ini, jenis penelitian yang digunakan termasuk jenis penelitian deskriptif dengan pendekatan kuantitatif. Menurut Arikunto (2003: 309), penelitian deskriptif merupakan penelitian yang dimaksudkan untuk mengumpulkan informasi mengenai status suatu gejala yang ada, yaitu keadaan gejala menurut apa adanya pada saat penelitian dilakukan. Penelitian ini menggunaakan pendekatan kuantitatif karena data yang ada berupa angka-angka atau simbol-simbol matematik yang terdapat dalam laporan keuangan dan dilakukan perhitungan-perhitungan terhadap data tersebut. (Sugitomo 2010;12). Penggunaan Metode Altman pada perusahaa, yaitu dengan cara menganalisis data-data laporan keuangan yang kemudian ditabulasikan untuk menentukan kategori perusahaan-perusahaan tersebut dapat dikatakan berpotensi bangkrut atau tidak. Sumber data yang digunakan dalam penelitian ini berupa data sekunder. 


\section{Teknik Pengumpulan Data.}

Untuk memudahkan peneliti dalam memperoleh data, maka diperlukan metodemetode pengumpulan data tertentu. Menurut Arikunto(2003:134), Metode pengumpulan data adalah cara-cara yang dapat digunakan oleh peneliti untuk mengumpulkan data. Penelitian ini memakai

Untuk mendapatkan data yang diperlukan, maka teknik pengumpulan data yang akan dipergunakan dalam penelitian ini adalah :

a. Studi dokumentasi, yaitu studi yang digunakan untuk mencari dan memperoleh hal-hal yang berupa catatan-catatan, laporan-laporan serta dokumen-dokumen yang berkaaitan dengan masalah yang diteliti dan melihat serta melakukan analisis terhadap laporan keuangan yang terdiri dari neraca, laporan laba/rugi dan arus kas.. Dokumentasi data historis laporan keuangan bank konvensional dan syariah didapatkan dengan membuka website dari objek bank yang diteliti, sehingga dapat diperoleh laporan keuangan yang telah diaudit selama tahun 2013-2017.

b. Studi pustaka, yaitu mengumpulkan data yang bersifat teoritis mengenai permasalahan yang berkaitan dengan penelitian ini. Metode ini dilakukan untuk menunjang kelengkapan data dengan menggunakan buku-buku literature, jurnal serta hasil penelitian yang berhubungan dengan masalah potensi kebangkrutan bank konvensional dan syariah.

\section{Kesimpulan:}

Skala pengukuran yang digunakan utuk mengukur variabel penelitian ini adalah skala rasio (perbandingan). Fungsi diskriminan (Z) diaplikasikan untuk menguji peranan sejumlah predictors atau variabel dependen tersebut ditransformasikan dalam logaritma untuk menormalkan distribusinya. Kemudian untuk menentukan kondisi keuangan dalam suatu perusahaan, dibagi dalam beberapa tingkatan atau kategori yaitu bangkrut atau tidak bangkrut Altman (1998), yaitu :

1.Apabila nilai Z-Score lebih kecil atau sama dengan 1,81 (Z-Score < 1,81), berarti perusahaan mengalami kesulitan keuangan dengan resiko yang tinggi akan kebangkrutan.

2. Apabila diperoleh nilai Z-Score antara 1,81 sampai dengan 2,99 $(1,81<Z$-Score < $2,99)$, pada grey area ini ada kemungkinan perusahaan bangkrut dan ada pula tidak. Oleh karena itu, perusahaan harus dapat segera mengambil tindakan untuk mengatasi masalah yang dialami oleh perusahaan.

3. Apabila nilai Z-Score lebih besar dari 2,99 (Z-Score > 2,99), memberikan penilaian bahwa perusahaan berada dalam keadaan yang sangat sehat sehingga kemungkinan kebangkrutan sangat kecil terjadi. 


\section{Jurnal Ecobisma Vol 5 No. 2 Juni 2018}

\section{DAFTAR PUSTAKA}

Arikunto, Suharsini,2003. Manajemen Penelitian, Cetakan Keenam, Jakarta: Rineka Cipta.

Altman,E.I.(1998), Financial Ratios, Discriminant Analysis and Prediction of Corporate Bancruptcy, The Jurnal of Finance, September, hal. 589-609.

(1994), Corporate Distress Diagnosis: Comparison Using Linier Discriminant Analysis and Neutral Network (The Italian Experience), Journal of Banking and Finance, hal. 505-525.

Agus Sartono, Manajemen Keuangan Teori dan Aplikasi, (Yogyakarta: BPFE, 2008) hlm.114.

Adnan,Hafiz dan Dicky Arisudhana, “ Analisis Kebangkrutan Model Altman Z-Score dan Springate pada Perusahaan Industri Property”.Jakarta: Jurnal Ekonomi Vol.1 No.1-6, 2012.

Amin Jan and Maran, (2015), Bankruptcy and Sustainability: A Conceptual Review on Islamic Banking Industry, Global Business and Management Research :An International Journal , Vol.7. No.1.hlm 109-138

Brigham, E.F. (1991), Dasar-Dasar Manajemen Keuangan, Jilid Satu, Edisi Ketujuh , Cetakan Ketiga, Penerbit: Erlangga, Jakarta.

Beaver, W.H. (1996), Financial ratios as Predictor of Failure: Emperical Research in Accounting, Suplement to Journal of Accounting Research, hal.71-111. , (1998), Market Price, Financial Ratios and Prediction of Failure, Journal of Accounting Research, Autumn, hal 59-82.

Bank Indonesia:2004

Dahlan Siamat, Manajemen Bank Umum, Jakarta: Penerbit Intermedia, 1993.h.266.

Dwi Nuraini Ilhamdan Sharfina Putri Kartika, Potensi Kebangkrutan Pada Sektor Perbankan Syariah untuk Menghadapi Perubahan Lingkungan Bisnis, Jurnal Ekonomi ,Vol 14 No.2 Oktober 2015, hlm 114.

Departemen Pendidikan Nasional, Kamus Besar Bahasa Indonesia, (Jakarta:PT.Gramedia Pustaka Utama, 2008), hlm 1096.

Didin Hafifuddin,Prof,Dr,KH,MS, dan Henri Tanjung,Ph.D, Pengantar Manajemen Syariah, hal.43

Edy Wibowo,dkk (2005), Mengapa Memilih Bank Syariah?, Bogor:Ghalia Indonesia, cetakan.I,hal. 33

Eungene F. Brigham dan Joel F. Houaton, Manajemen Keuangan , Erlangga, Jakarta, 2001, hal. 36.

Ensiklopedia Indonesia, Departeman Pendidikan dan Kebudayaan, (Jakarta :Pakhi Pamungkas, 1997), hlm, 358

Fauzia, Ika Yunia."Mendeteksi Kebangkrutan Secara Dini Perspektif Ekonomi Islam", Jurnal Ekonomi dan Keuangan . Maret 2015.Vol.19No.1

Hilman Abrori, Analisis Perbandingan Risiko Kebangkrutan pada Bank Syariah Devisa dan Non Devisa dengan menggunakan Metode Altman Z-Score, (Semarang:UIN Walisongo, 2015) hlm.8

Jumingan (2006), Analisis Laporan Kuangan, Jakarta. PT.Bumi Aksara, hal .242. 
Jogiyanto (2000), Teori Portofolio dan Analisi Investasi, BPEE UGM, Yogyakarta, hal 570 .

Kuncoro, Mudrajat, (1990), Metode Riset Untuk Bisnis dan Ekonomi, Edisi Kedua, Penerbit: Erlangga Jakarta.

Kordestani,dkk, (2011). Ability of Combinations of Cash Flow Components to Predict Financial Distress. Business : Theory and Practice, 277-285,.

, (2003), Metode Riset untuk Bisnis dan Ekonomi, Bagaimana meneliti dan menulis tesis?, Jakarta. Erlangga.

Kasmir. 2010. Pengantar Manajemen Keuangan. Edisi Pertama. Jakarta: Kencana.

, Dasar-Dasar Perbankan (Jakarta: Raja Grafindo Persada, 2007), hlm. 215217

Lukman Dendawijaya, Lima Tahun Penyehatan Perbankan Nasional 1998-2003, (Jakarta :Ghalia Indonesia, 2004), hlm 193.

Machfoedz,M. (1999), Profil Kinerja Finansial Perusahaan-Perusahaan Yang G0Publik di Pasar Modal ASEAN, Journal Ekonomi dan Bisnis Internasional, No.1, hal. 56-72.

M.Syafi'i Antonio, Dasar-Dasar Manajemen Bank Syariah, Jakarta: Pustaka Alfabeta, cetakan ke-4, 2006, hal.2

Munawir, S.2000. Analisa Laporan Keuangan . Edisi Keempat, Yogyakarta: Liberty

Muhammad Akhyar Adnan dan Eha Kurniasih,"Analisa Tingkat Kesehatan Perusahaan Untuk Memprediksi Potensi Kebangkrutan Dengan Pendekatan Altman",dalam Jurnal Akuntansi dan Auditing Indonesia, Vol.4, No.2.2000,h.137.

Muhammad, Manajemen Pembiayaan Bank Syari'ah, (Yoyakarta:UPP AMP YKPN, 2005), hlm.1.

Melan Rahmaniah dan Hendro Wibowo, Analisis Potensi Terjadinya Financial DistressPada Bank Umum Syariah (BUS) di Indonesia, (Jurnal Ekonomi dan Perbankan SyariahVol.3.No.1, April 2015, hlm.2.

Sartono, A.I. (2001), Manajemen Keuangan: Teori dan Aplikasinya, Edisi Keempat, Cetakan Pertama, Penerbit: BPFE, Yogykarta.

Sawir, Agoes, (2001), Analisis Kinerja Keuangan dan Perencanaan Keuangan Perusahaan, PT,Gramedia Pustaka Utama, Jakarta.

Sinkey, Joseph, F. Jr (1995) A Multivariate Statistical Analisis of The Characteristics of problem Bank, The Journal of Finance, hal 21-36

Sugiyono, (2012), Metode Penelitian Bisnis, Cetakan Ke-16, Penerbit CV.ALFABETA, Bandung, hal. 115.

Suharso,Drs dkk, Kamus Besar Bahasa Indonesia Edisi Lux, Semarang; CV.Widya Karya, hal.75

Pengantar Manajemen Syariah, Prof.Dr.KH.Didin Hafifuddin,MS dan H.Hendri Tanjung,Ph.D, hal.43

Thomson, James.B (1991). Predicting Bank Failure Journal in The 1980, Economic Review(First Quarter), hal.9-20. 


\section{Jurnal Ecobisma Vol 5 No. 2 Juni 2018}

Teng. Michael. 2002. Corporate Turn Around Nursing A Sick Company Back to Health. Diterjemahkan oleh Barlian Muhammad, Jakarta: Pearson Education Asia Pie. Ltd dan PT.Prenhallindo.

Tristantyo, Yoga Rhesana, Analisis Model Altman Z-Score dalam memprediksi kebangkrutan pada perusahaan perbankan swasta nasional devisa yang go public di BEI, Universitas Widyatama, Bandung: 2013, hlm,2.

Undang-Undang No.21 Tahun 2008 Tentang Perbankan Syariah. Perbankan Syariah, Ketentuan Umum, Pasal 1, ayat 4.

Undang-Undang No.10 Tahun 1998, tentang perbankan (Bab II, Pasal: 4)

Zainul Arifin, (2009), Dasar-Dasar Manajemen Bank Syariah , (Jakarta: Azka publisher), hal.15

Teori Keuangan dan Pasar Modal, Ekonosia, Yogyakarta, 2005, hal. 11. 